\title{
MEASURING THE EFFICIENCY OF TOURIST ATTRACTION MANAGEMENT IN NORTH TORAJA REGENCY, INDONESIA
}

\author{
NURFAIDA $^{1 *}$, HADI SUSILO ARIFIN² ${ }^{2}$ SANTUN RISMA PANDAPOTAN SITORUS ${ }^{3}$ AND \\ ERIYATNO ${ }^{4}$
}

\begin{abstract}
${ }^{1}$ Study Program of Natural Resources and Environmental Management Science, Graduate School of Bogor Agricultural University (IPB), Baranangsiang IPB Campus, Bogor 16144 Indonesia. ${ }^{2}$ Department of Landscape Architecture, Faculty of Agriculture, Bogor Agricultural University (IPB), Darmaga IPB Campus, Bogor 16680, Indonesia. ${ }^{3}$ Department of Soil Science and Land Resources, Faculty of Agriculture, Bogor Agricultural University (IPB), Darmaga IPB Campus, Bogor 16680, Indonesia. ${ }^{4}$ Center for Agriculture and Rural Development Studies, Bogor Agricultural University (IPB), Baranangsiang IPB Campus, Bogor 16144, Indonesia.
\end{abstract}

*Corresponding author: nurfaida@yahoo.com

Submitted final draft: 25 December 2020 Accepted: 26 January 2021

http://doi.org/10.46754/jssm.2021.10.011

\begin{abstract}
North Toraja Regency has around 292 tourist attractions that are spread throughout its sub-districts. However, several tourist attractions have not been entirely managed optimally. This study's objective was to evaluate the efficiency of the management of tourist attractions in North Toraja Regency. A field survey was conducted at 21 tourist attractions using the Data Envelopment Analysis (DEA) method. The tourist attractions included 11 attractions managed by foundations, 9 attractions managed by non-foundations (families or farmers), and 1 attraction managed by the local government. The DEA analysis result based on an output orientation with the assumption of Constant Return to Scale (CRS) showed that 7 tourism objects or Decision-Making Units (DMUs) are categorised as efficient with a value of $\theta=1$. The efficient units were Ke'te' Kesu, Singki' Cross, Palawa', Ne' Gandeng Museum, Londa, Sinar Lempe, and Lolai To'tombi. From the 7 efficient DMUs, 6 DMUs can become references for other DMUs, which had inefficient management. This study's result is expected to help managers and local governments improve tourist attractions management's performance.
\end{abstract}

Keywords: Data envelopment analysis, performance, productivity, tourism.

\section{Introduction}

Tourism is the largest industry globally (Sofronov, 2018), and it has been experiencing rapid growth (Szpilko, 2017)in the market of tourist services, can be provided by innovative products comprising a response to the everincreasing customer expectations. The specificity of product development in the tourism industry requires the commitment and cooperation of many partners - operators in the tourist supply chain. The purpose of this article is to identify the areas of research analysed in the international literature in the field of tourism supply chain, published in the Web of Science. The results of the analysis are presented in the form of a map of themes (research areas. The tourism industry is a driver of economic growth that can generate employment and increase foreign exchange earnings (Khan et al., 2020). The arrival and reception of international tourists in Southeast Asia's tourism destination countries, including Indonesia, have increased yearly. This can be observed from the strong growth in most tourism destinations (World Tourism Organisation, 2019). The tourism sector ranks fourth in Indonesia's foreign exchange earnings, with a contribution of USD 10.1 billion in 2013, USD 11.2 billion in 2014, and USD 12.2 billion in 2015. The tourism sector's foreign exchange earnings experienced an increase in 2016, which was ranked second after the palm oil industry (CPO) with foreign exchange earnings of USD 13.6 billion. Likewise, in the following years, there was an increase in foreign exchange earnings in the tourism sector, i.e., USD 15.0 billion in 2017, USD 16.1 billion in 2018 (Kemenpar, 2019), and USD 17.6 billion in 2019. 
One of the regencies that have attractive natural and cultural potential for tourism is North Toraja Regency. Toraja is one of the 50 National Tourism Destinations and 88 National Tourism Strategic Areas based on Government Regulation of the Republic of Indonesia Number 50 of 2011 regarding the National Tourism Development Master Plan for 2010-2025. North Toraja Regency's main strength is the tourism sector, hence that all its potential is directed to support the tourism sector. The development of the tourism sector is aimed at increasing tourist visits, both domestic and foreign tourists. Tourists started visiting Toraja in the 1960s, with the peak of tourist visits being in 1997, which reached 300,000 foreign tourists (Malamassam, 2018). Toraja's tourism destinations' main market is European visitors, indicated by the largest number of tourist arrivals for several years from France, Netherlands, Spain, Germany, and Italy. The number of tourists in 2018 originating from France amounted to 6,579 people $(12.36 \%)$, Netherlands 2,741 people (5.15\%), Spain 2,653 people $(4.99 \%)$, Germany 1,955 people (3.67 $\%$ ), and Italy by 1,169 people $(2.20 \%)$ (BPS Kabupaten Toraja Utara, 2019). Currently, tourists from Asian countries have also started visiting North Toraja Regency, such as tourists from Japan, Singapore, Malaysia, China, and India.

The North Toraja Regency government has made efforts to increase tourist numbers by optimising marketing, diversifying destinations, and improving potential tourist attractions. One of the local government programmes is to increase the number of tourist attractions. Tourist attractions, according to Law Number 10 of 2009 regarding Tourism, are anything that has uniqueness, beauty, and diversity value in the form of natural, cultural, and human-made resources or targeted tourist visit destinations. Tourist attractions have a major component that can attract people to visit a place, either to see something or participate in an activity (Liu \& Ko, 2011). This attraction can be in the form of a mixture of tangible and intangible assets, including the person who manages the attraction (Erislan, 2016).
Based on the North Toraja Regent Decree Number 380/XI/2016 regarding Determination of Tourist Attractions in North Toraja Regency and Number 299/IX/2018 Re-Determination of Tourist Attractions in North Toraja Regency, there are 296 tourist attractions in sub-districts in North Toraja Regency. However, not all these tourist attractions have been managed optimally. Tourist interest in North Toraja Regency must be supported by adequate tourism support facilities. One aspect that needs to be managed properly is amenities, including cleanliness and tourism support facilities. Tourism support facilities are an integral part of the physical infrastructure that is inseparable from tourism development (Jafari \& Xiao, 2016). The availability of tourism support facilities can increase tourist destinations' attractiveness and competitiveness (Mandic et al., 2018). Tourists who visit tourist attractions expect convenience and comfort because of the tourism support facilities. However, tourism support facilities in several tourist attractions are inadequate and even unavailable. Efforts to improve the management of tourism support facilities need to be made to increase management productivity. Therefore, it is important to have information on tourist attractions' productivity in North Toraja Regency.

Productivity in the service industry, including tourism, can be measured based on two main concepts, i.e., effectiveness and efficiency (Sherman \& Zhu, 2006). The concept of effectiveness refers to the setting and achieving of goals and objectives, while efficiency refers to producing outputs with minimal inputs (Chen et al., 2008). Efficiency indicators are important in developing the tourism industry, so they must be evaluated (Yi \& Liang, 2014). One of the key evaluation indicators is performance by using efficiency measures. Efficiency can be classified into four components, i.e., price efficiency, allocative efficiency, technical efficiency, and scale efficiency. Price efficiency is achieved by using minimum inputs without sacrificing quality, while allocative efficiency is achieved by using a combination of optimal inputs to produce outputs. Technical efficiency, known 
as global efficiency, is achieved by producing better outputs with existing inputs or the same outputs with fewer inputs. Scale efficiency refers to components that can change the optimal level of an activity to produce more or less similar to the optimal level with impact to costs (Sherman \& Zhu, 2006).

Efficiency measurements can be performed using two methodologies, i.e., parametric and non-parametric. Analysis of the parametric method is carried out by establishing the production function and considering changes that can affect it. In contrast, the non-parametric method is carried out without establishing the production function (Oukil et al., 2016). The parametric method allows for error measurements (Alzua-Sorzabal et al., 2015) for example, by using regression analysis, factor analysis, and stochastic approaches. The non-parametric method are done by using a linear programming approach, such as data envelopment analysis, backward uncertainty propagation, artificial neural networks, and hierarchical analysis (Yi \& Liang, 2014). One method that is widely used to measure efficiency is Data Envelopment Analysis (DEA). Farrel first developed this method in 1975 based on the production theory on a single input and a single output (Cooper et al., 2000). However, this method does not fully represent efficiency because to produce both single and more outputs, it takes several inputs (Sherman \& Zhu, 2006). The DEA method was later modified by Charnes, Cooper, and Rhodes in 1978 (Klimberg et al., 2009), which changed the original equation by including measurements of several inputs and outputs (Sherman \& Zhu, 2006).

The DEA method has been widely used to evaluate the performance of various fields, such as health (Kohl et al., 2019), education (Agasisti et al., 2019), the automotive industry (Jiang et al., 2018), and banking (Othman et al., 2016). Likewise, with the tourism industry, DEA is widely used mainly in hotels (Assaf, 2012), travel agents (Fuentes, 2011), and restaurants (Mhlanga, 2018). Efficiency studies on tour operators and hotel companies in several Asia
Pacific countries show that international hotels have higher efficiency than local hotels. This study also identified a list of the most efficient tour operators and hotels (Assaf, 2012). The DEA method has been used to assess the productivity of star hotels in China. The findings show that the number of hotels can be reduced to maximise total sales revenue and occupancy percentage (Tsai, 2009). This method is also used to determine the performance of hotel services in the Portuguese region. This study indicates that hotels' star rating is not a significant determinant of service (Oliveira et al., 2013) the comparison being made between those hotels possessing golf courses and those that do not. The Algarve is one of the more important tourism locations in Portugal and a popular destination for tourists from many countries and specifically attracts tourists seeking to play golf. By using data envelopment analysis (DEA). Apart from assessing microscale productivity, the DEA method is also used at a macro scale to determine the relationship between tourism and economic growth in European, Asian, and African countries. The results show a two-way causality relationship between tourism and economic growth in Europe and Asia. However, this is not the case in Africa, where there is no causal relationship between tourism and economic growth (Tugcu, 2014). Research using the DEA method provides useful insights and implications for the tourism sector. Research on tourism efficiency in China shows that trade openness, climate change, and market intensity can increase China's tourism efficiency (Chaabouni, 2019). In the context of sustainability analysis, DEA has only been used in the last two decades (Fauzi, 2019). The DEA method becomes an important tool in analysing sustainability in various fields (Zhou et al., 2018).

Measurement of efficiency is important for tourism managers in conducting performance benchmarks for future improvement (Mostafa, 2007). Nevertheless, studies on the measurement of efficiency of tourist attractions management have been lacking. Interest in a tourist destination is closely related to the availability of tourist 
facilities. However, the more tourist facilities provided, the higher the costs will be incurred in managing the tourist attractions. Therefore, knowing the efficiency of managing tourist attractions based on the inputs and outputs is very important. This study's objective is to evaluate the efficiency of the management of tourist attractions in North Toraja Regency. This study's result is expected to help managers and local governments improve tourist attractions management' performance.

\section{Materials and Methods}

This study was conducted in North Toraja Regency, South Sulawesi Province, Indonesia, at 21 tourist attractions (Figure 1). North Toraja Regency has 292 tourist attractions, but only 21 tourist attractions have signed an agreement with the local government regarding retribution distribution. The tourist attractions should deposit retribution fees to the local government of North Toraja Regency. They are assessed for efficiency in managing tourist attractions. Field research activities were carried out from August 2018 to January 2019. Data collection was carried out using field surveys and interviews with managers and related agencies.

The measurement of tourist attractions' management efficiency was performed using the Data Envelopment Analysis (DEA) method. DEA was developed as a tool for analysis and benchmarking using a linear programming model. DEA is a non-parametric method for assessing a Decision-Making Unit (DMU) (Despotis \& Smirlis, 2002)inputs and outputs are measured by exact values on a ratio scale. Cooper et al. [Management Science, 45 (1999. DMU can be assessed in sectors, regions, working units, organisations, and its kind. DEA was used to measure the DMU's efficiency through the weighted output with the weighted input ratio of each DMU. Also, DEA analysis allows the use of multi-input and multi-output (Soysal-Kurt, 2017). DEA has the advantage of

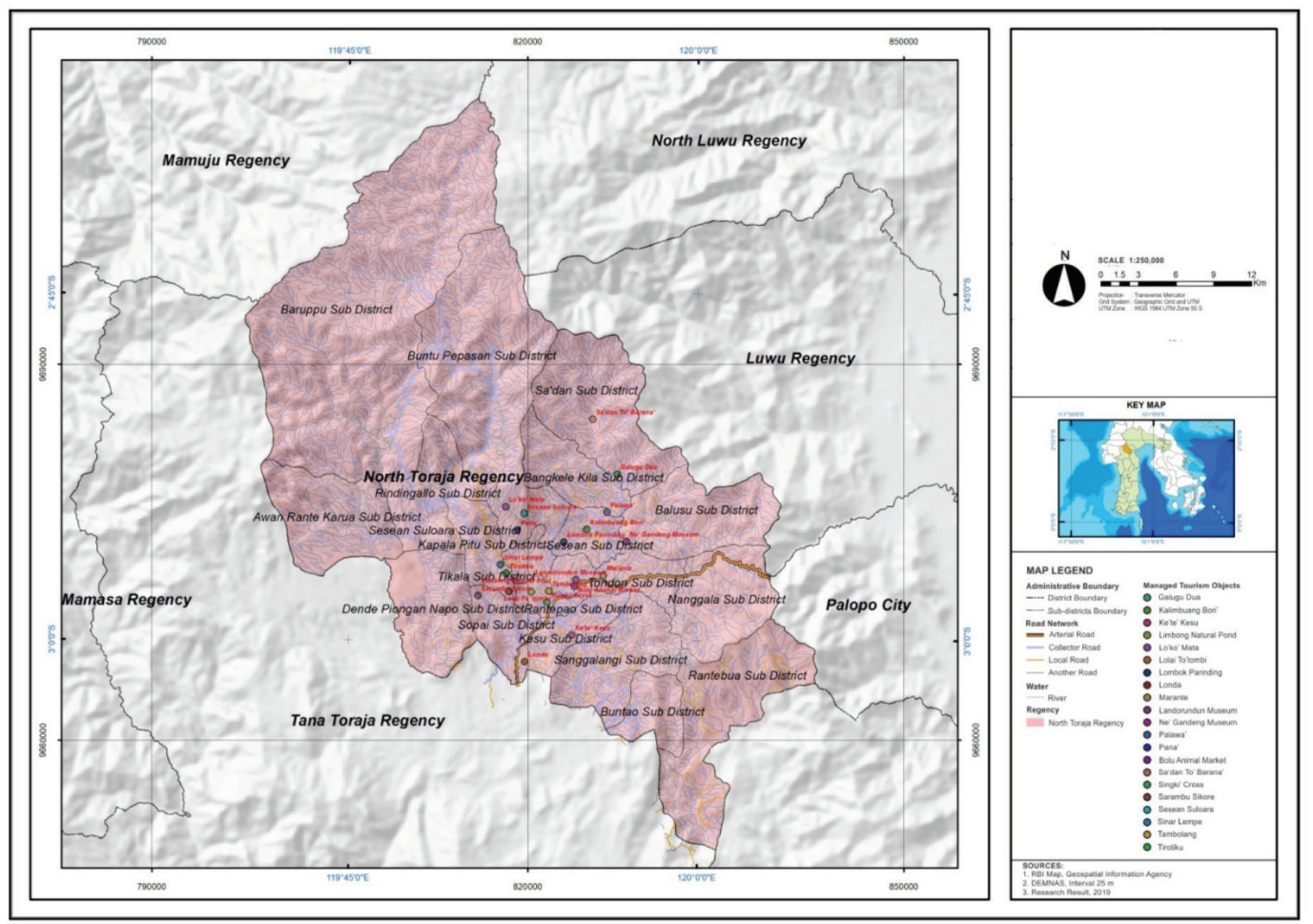

Figure 1: Study location of 21 tourist attractions in North Toraja Regency 
being a powerful benchmarking analytical tool and can produce performance improvements from inefficient units.

DEA's efficiency is the relative efficiency obtained from comparing DMUs that are evaluated with other DMUs in a given period (Yi \& Liang, 2014). This relative efficiency was relative to the unit that has the best performance. The best unit performance was given a score of 1 or $100 \%$, while other DMU performances varied from 0 to 1 or 0 (lowest) to $100 \%$ (highest) relative to the best unit (Fauzi, 2019). The DMU management of tourism attractions was quite efficient if the value is equal to 1 or $100 \%$. In contrast, it is inefficient if the value was less than 1 or less than $100 \%$. Inefficiency occurs due to differences in size, volume, and/or other factors called scale.

The DEA method can be analysed with two model assumptions, i.e., Constant Return to Scale (CRS) and Variable Return to Scale (VRS). The CRS model assumes that the scale and efficiency of the DMU have no substantial relationship, so that an increase in the input will proportionally increase output by the same proportion (the proportion of input is directly proportional to the proportion of output). For example, if the input is increased by $1 \%$, the output will also increase by $1 \%$. In contrast to the CRS model, in the production process using the VRS model, there is a constant increase, decrease, and return of scale (Soysal-Kurt, 2017). In some situations, the rate of substitution between input and output is disproportionate. Using the VRS assumption, this situation can be identified through analysing the unit's return to scale, i.e. whether the unit is on the Increasing Return to Scale (IRS) or Decreasing Return to Scale (DRS). IRS occurs when an increase in the input will proportionally increase the output more than the proportion of an increase in input. If the input is increased by $\delta$ and the proportion of the increase in output occurs by $\gamma$, then IRS is determined when $\gamma<\delta$. If the opposite occurs, i.e., $\gamma>\delta$, this situation describes DRS. The CRS model is the default model when processing input data in the DEA software (Fauzi, 2019).
In addition to distribution based on scale, the DEA method has two analysis orientations, i.e., input orientation and output orientation. The difference between these two orientations is the main factor used as the basis for the analysis. The main factor in the input orientation is the input variable, while the output orientation is the output variable. Therefore, the main purpose of input orientation is to minimise the number of inputs to produce a predetermined output. The main objective of output orientation is to produce maximum output using predetermined inputs (Soysal-Kurt, 2017). This study uses a CRS model with an output orientation to see the number of visitors and the optimal income tourist attraction manager.

\section{Results and Discussion}

North Toraja Regency has tourism potential, especially in terms of culture, and is known for its uniqueness and authenticity as a tourist attraction. Also, there are natural and agricultural potentials that are interesting to visitors. Natural attractions in North Toraja Regency include landscapes in the form of karst mountains, natural pools, rivers, waterfalls, dunes, forest areas, rice fields, plantations, flora, and fauna. In contrast, known human-made attractions include, for example, traditional houses (tongkonan), stone graves, and traditional death ceremonies ( $\mathrm{rambu}$ solo'). These attractions can be found in tourist attractions scattered throughout the region of North Toraja Regency. The largest tourist attractions are located in Sesean and Balusu sub-districts, with 24 objects, respectively. In comparison, the smallest number of tourist attractions is located in Buntao and Tondon sub-districts with 4 objects for each sub-district (Figure 2).

The management of tourist attractions in North Toraja Regency can be divided into three, i.e., foundations, non-foundations (families or farmers), and local government. Foundations and non-foundations generally carry out the management of the 21 tourist attractions in North Toraja Regency. A tourist attraction managed by the local government is the Bolu 


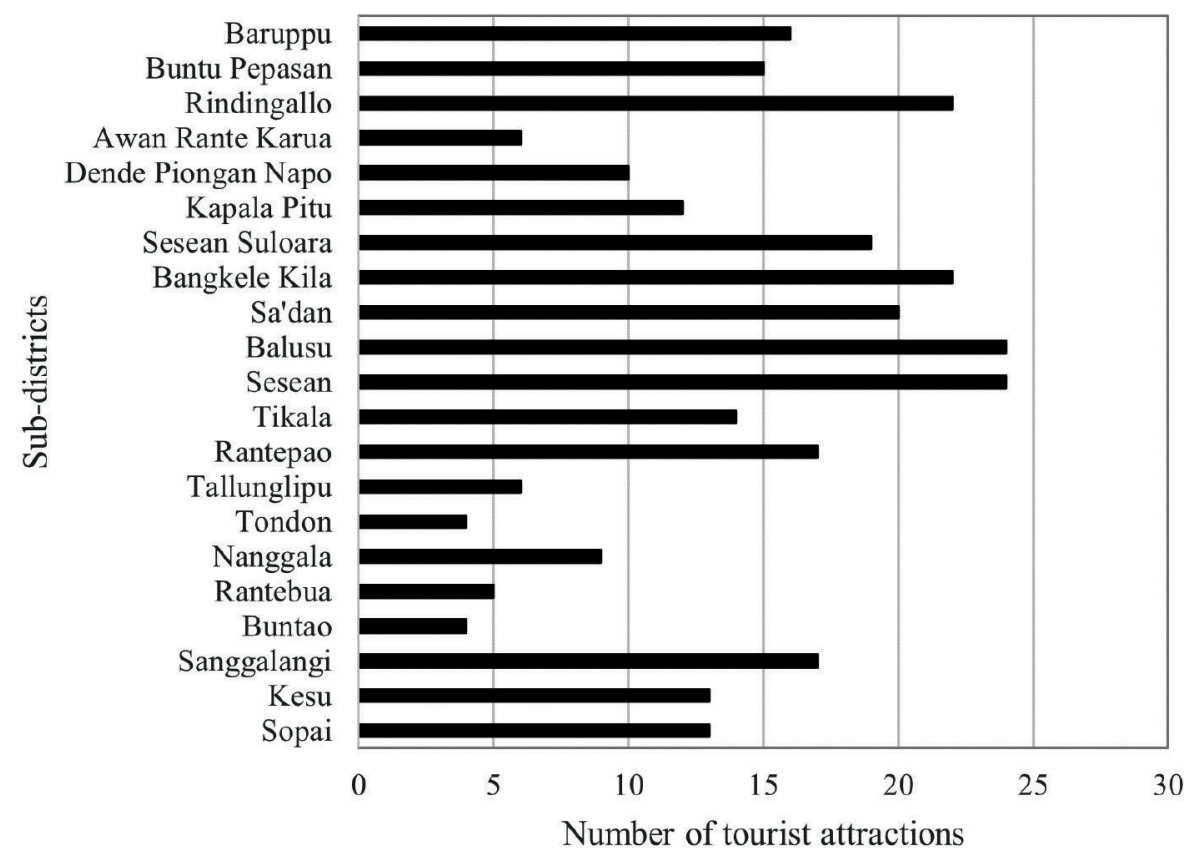

Figure 2: The number of tourist attractions based on sub-districts

Animal Market. The Bolu Animal Market is the largest traditional market in North Toraja Regency, which has a unique attraction because there is a special market for buffalo and pig livestock. Management of tourist attractions by foundations and non-foundations (families or farmers) in the regency is mostly attributed to ownership status. Cultural sites used as tourist attractions are historical treasures, heritages, and ancestral relics (Itamar et al., 2014) owned by many families. Some of these families live in North Toraja Regency, in other parts of Indonesia, or even live abroad (Junaid, 2015). Indeed, many Toraja people have migrated abroad and work to raise money for traditional ceremonies and buffalo slaughter. The nomads will return home for the traditional ceremony, which is usually held at the end of the year, coupled with Christmas celebrations. Therefore, to assist the management of cultural sites, foundations are usually formed. Foundations are organisations that work based on familial relationships to manage cultural sites (Junaid, 2015). The number of tourist attractions managed by foundations is 11 tourist attractions, such as the Ke'te' Kesu Foundation, which manages the Ke'te' Kesu tourist attraction; the Sangpetayanan Foundation, which manages Londa tourist attraction; To' Barana' Foundation, which manages the Sa'dan To' Barana' tourist attraction; the Kalimbuang Bori' Foundation, which manages the Kalimbuang Bori' tourist attraction; the Palawa' Foundation, which manages the Palawa tourist attraction; the Ne' Gandeng Foundation, which manages the Ne' Gandeng Museum tourist attraction; and, the Sinar Lempe Foundation, which manages the Sinar Lempe tourist attraction.

The North Toraja Regent Decree Number 56 of 2017 regarding Procedures for Collecting Recreational and Sports Retribution Fees stipulates that the proceeds distribution of the retributions fees of recreational and sports sites is distinguished for objects managed by foundations and non-foundations (families or farmers). For tourist attractions managed by foundations, the revenue sharing is $60 \%$ for foundations and $40 \%$ for the local government. In comparison, for tourist attractions managed by non-foundations, it is $50 \%$ for both parties, 
the non-foundations and the local government. Of the 21 tourist, $11(52 \%)$ tourist attractions were managed by foundations, $9(43 \%)$ by non-foundations (families or farmers), and 1 $(5 \%)$ by the local government (Table 1$)$. Tourist attractions in North Toraja Regency are divided into three types of objects, i.e., nature, culture, and agriculture. Generally, tourist attractions in this regency are of the cultural type, with attractions such as traditional houses and burial sites. The attractions of the natural type include waterfalls, natural pools, and natural landscapes, while the attraction of the agriculture type include coffee plantations.

Analysis of tourist attractions' management efficiency in the North Toraja Regency used two outputs and three inputs. The number of inputs used was higher than the outputs because the weighted outputs cannot be greater than the number of weighted inputs for each DMU (Soysal-Kurt, 2017). The output used were

Table 1: List of tourist attractions managed in North Toraja Regency

\begin{tabular}{|c|c|c|c|}
\hline No. & $\begin{array}{l}\text { Name of Tourist } \\
\text { Attractions }\end{array}$ & Attractions & $\begin{array}{c}\text { Management } \\
\text { Authority }\end{array}$ \\
\hline 1 & Ke'te' Kesu & Traditional village and burial place & Foundation \\
\hline 2 & Sesean Suloara & Coffee plantation & Family \\
\hline 3 & Sa'dan To' Barana' & Traditional weaving & Foundation \\
\hline 4 & Kalimbuang Bori’ & Burial site and megalith & Foundation \\
\hline 5 & Lo’ko' Mata & Stone grave & Foundation \\
\hline 6 & Tambolang & $\begin{array}{l}\text { Natural graves, natural landscapes and } \\
\text { views of the district capital }\end{array}$ & Family \\
\hline 7 & Singki' Cross & Monument statue & Family \\
\hline 8 & Sarambu Sikore & Waterfall & Family \\
\hline 9 & Bolu Animal Market & Traditional market & $\begin{array}{l}\text { Local } \\
\text { government }\end{array}$ \\
\hline 10 & Lombok Parinding & Cave burial site & Family \\
\hline 11 & Palawa' & Traditional village & Foundation \\
\hline 12 & $\begin{array}{l}\text { Limbong Natural } \\
\text { Pool }\end{array}$ & Natural pond & Family \\
\hline 13 & $\begin{array}{l}\text { Ne' Gandeng } \\
\text { Museum }\end{array}$ & Museum & Foundation \\
\hline 14 & Londa & Cave burial site & Foundation \\
\hline 15 & $\begin{array}{l}\text { Landorundun } \\
\text { Museum }\end{array}$ & Museum & Foundation \\
\hline 16 & Pana' & Stone graves and baby grave & Family \\
\hline 17 & Galugu Dua & Traditional village and weaving & Family \\
\hline 18 & Marante & Traditional village and burial sites & Family \\
\hline 19 & Sinar Lempe & Traditional village and natural scenery & Foundation \\
\hline 20 & Tirotiku & $\begin{array}{l}\text { Natural panorama of pine forests and the } \\
\text { sensations of being upon the clouds }\end{array}$ & Foundation \\
\hline 21 & Lolai To'tombi & $\begin{array}{l}\text { Natural panorama of pine forests and the } \\
\text { sensations of being upon the clouds }\end{array}$ & Foundation \\
\hline
\end{tabular}

Source: North Toraja Regency Culture and Tourism Office (2018) 
visitors (output 1) and total income (output 2), while the input used was labour (input 1), toilet facilities (input 2), and expenditure for the local government (input 3). The use of these inputs and outputs was considered relevant in assessing tourism attractions' management efficiency in North Toraja Regency. Also, all the necessary data was available. The DMU in this paper were 21 DMUs of tourism attractions that have been managed. The number of inputs, outputs, and DMUs had fulfilled the requirements for DEA analysis, with the DMU must be twice the number of the outputs and inputs (Zhang \& Guo, 2004). The value entered in the DEA software used a small value because the smaller the value used, the better (Fauzi, 2019). The value for visitors was valued in one hundred, while the value for total income and local government expenditure was valued in one million.

This study used the output orientation method with the assumption of Constant Return to Scale (CRS). The selection of orientation influenced efficiency results to require good consideration (Assaf \& Josiassen, 2015). There is no clear argument about the best orientation to choose in economic literature because it is highly dependent on market conditions (Barros, 2005). However, the output orientation model is generally the most realistic choice because it can motivate managers to maximise the obtained results (Assaf \& Josiassen, 2012). The selection of output orientation in this study was based on why North Toraja Regency's development target in the tourism sector increased the number of tourist visits, so various efforts are needed to achieve this target. Despite this, managers have limitations in providing inputs, such as labour and tourism support facilities. Also, input in the form of expenditures for the local government has been regulated by the Regent's decision, a reference for all managers of recreational and sports sites in the revenue distribution of the retribution fees. Therefore, with existing resources, efforts must be made to optimise output; in this case, the number of visitors and total income.
DEA analysis results based on an output orientation with the CRS assumption indicated 7 efficient DMUs and 14 inefficient DMUs. 7 DMUs had values of between $81 \%$ and $99.9 \%$, and 7 DMUs had values $<80 \%$. Tourist attractions as an efficient unit with a value of $\theta$ $=1$ or $100 \%$ were DMU 1 (Ke'te' Kesu), DMU 7 (Singki' Cross), DMU 11 (Palawa'), DMU 13 (Ne' Gandeng Museum), DMU 14 (Londa), DMU 19 (Sinar Lempe), and DMU 21 (Lolai To'tombi) (Table 2). The management efficiency of tourist attractions using the DEA model was obtained by comparing the evaluated DMUs with other DMUs in 2018. Efficient units were references for other inefficient units that can be known from peers. Peers value and peers weight value for each DMU illustrated the benchmark for DMU to be efficient (Fauzi, 2019).

Table 2: Efficiency scores of tourist attractions

\begin{tabular}{clc}
\hline DMU & Tourist Attractions & $\begin{array}{c}\text { Efficiency } \\
\text { Scores }\end{array}$ \\
\hline 1 & Ke'te' Kesu & 1.000 \\
2 & Sesean Suloara & 0.916 \\
3 & Sa'dan To' Barana' & 0.943 \\
4 & Kalimbuang Bori' & 0.997 \\
5 & Lo'ko' Mata & 0.928 \\
6 & Tambolang & 0.921 \\
7 & Singki' Cross & 1.000 \\
8 & Sarambu Sikore & 0.727 \\
9 & Bolu Animal Market & 0.389 \\
10 & Lombok Parinding & 0.754 \\
11 & Palawa' & 1.000 \\
12 & Limbong Natural Pool & 0.797 \\
13 & Ne' Gandeng Museum & 1.000 \\
14 & Londa & 1.000 \\
15 & Landorundun Museum & 0.952 \\
16 & Pana' & 0.727 \\
17 & Galugu Dua & 0.667 \\
18 & Marante & 0.667 \\
19 & Sinar Lempe & 1.000 \\
20 & Tirotiku & 0.952 \\
21 & Lolai To'tombi & 1.000 \\
\hline & Mean & 0.873 \\
\hline & & \\
& & \\
\hline
\end{tabular}


Inefficient units that generated values of $\theta<1$ or less than $100 \%$ were DMU 2 (Sesean Suloara), DMU 3 (Sa'dan To' Barana), DMU 4 (Kalimbuang Bori'), DMU 5 (Lo'ko' Mata), DMU 6 (Tambolang), DMU 8 (Sarambu Sikore), DMU 9 (Bolu Animal Market), DMU 10 (Lombok Parinding), DMU 12 (Limbong Natural Pool), DMU 15 (Landorundun Museum), DMU 16 (Pana'), DMU 17 (Galugu Dua), DMU 18 (Marante), and DMU 20 (Titotiku). These units were categorised as inefficient because the input they have should be able to produce a larger output. Optimal efficiency will be achieved if the output per input can be fulfilled. For example, DMU 2 (Sesean Suloara) had a technical efficiency value of $\theta=0.916$ or $91.6 \%$, which refers to three peers, i.e., DMU 1, DMU 19, and DMU 21. The lambda weight of each referred peer was DMU 1 (Ke'te' Kesu) of $\lambda_{1}=0.035$, DMU 19 (Sinar Lempe) of $\lambda_{19}=$ 0.133 , and DMU 21 (Lolai To'tombi) of $\lambda_{21}=$ 0.073 . Approximately 4,900 tourists visited this tourist attraction in 2018, with an income of IDR 69 million. To achieve efficiency, DMU 2 can use inputs to increase outputs. The projected value for each input and output variable can be determined by multiplying the weight of peers with the input and output variables from the peers so that the optimal value in DMU 2 was positioned in a value of 53.501 for output 1 with a radial movement of 4.501, a value of 75.339 for output 2 with a radial movement of 6.339 , a value of 2.796 for input 1 with a slack movement of -2.204 , a value of 1.000 for input 2 , and a value of 31.000 for input 3 . This means that DMU 2, in this case, the Sesean Suloara tourist attraction, which had a labour input of 5 people, 1 toilet facility, and expenditure for the local government of IDR 31 million, can increase the number of visitors by 53,501 people and obtain a total income of IDR 75,339 million. The number of labour inputs can also be reduced to 3 people in achieving this output. Likewise, interpretations for other inefficient DMUs can use the same analogy as DMU 2.

Tourist attractions that are considered to have inefficient management can become efficient by reducing inputs or optimising existing inputs. The owned inputs include labour, toilet facilities, and payments to the local government, can be optimised to produce a greater output. Besides, inefficient tourist attractions can refer to tourist attractions that are already efficient to increase their management's productivity. Inputs that can be optimised are labour and toilet facilities. Simultaneously, deposits to the local government through North Toraja Regency Culture and the Tourism Office are regulated under North Toraja Regent Decree Number 56 of 2017 regarding Procedures for Collecting Retribution for Recreational and Sports Places. In this decree, the amount of profit-sharing from recreation and sports levies has been stipulated, which must be deposited by the manager of the tourist attractions so that it is difficult to reduce the amount.

One of the tourist attractions that is classified as efficient in its management is Ke'te' Kesu. This tourist attraction can be a reference in management, especially for tourist attractions that have inefficient management. The input of the labour of 21 people, toilet facilities of 5 units, and deposit to the local government of IDR 496 million achieved tourist visits of 78,600 and income of IDR 1,240 million. Ke'te' Kesu is the most visited tourist attraction with the number of visits in 2018 consisting of 10,450 foreign tourists, 61,200 domestic tourists, 1,000 local government-related people, and 5,900 students. The revenue of the Ke'te' Kesu tourist attraction in 2018 after deducting the North Toraja Regency Regional Budget deposit was IDR 743.94 million.

Ke'te' Kesu is a cultural tourist attraction that has unique attractions, such as traditional houses (tongkonan) and burial sites. This tourist attraction, which is managed by the Ke'te' Kesu Foundation, has a tourism governing body with an organisational structure of chairman, vicechairman, secretary, treasurer, and the vicetreasurer. Besides, in the foundation, some families are members of the management of tourist attractions. These families, represented by family members, take turns serving at the ticket counters every month. The task schedule 
for maintaining ticket counters is arranged in a year-long labour management plan by the tourist attraction manager. Besides, the manager has also made a budget allocation from the received income (Table 3). The largest budget allocation (40\%) was deposited to the Regional Government Budget of North Toraja Regency. The next allocation was for manager incentives of $12 \%$, maintenance of buildings and areas of $10 \%$, collection wages of $7 \%$, and preservation reserves of $7 \%$. Collected wages are costs allocated to people who manage or repair damage at the tourist attraction site. The elements that include bill wages, among others, are counter keepers, toilet repairing costs, site arrangement costs, electricity repairing costs, and road repairing costs. Maintenance costs for buildings and areas are used to repair damaged traditional houses (tongkonan) and rice barns (alang). For example, the cost of repairing the roof of a traditional house can cost around IDR 20 million (Palalangan et al., 2019).

Table 3: Foundation budget allocation for Ke'te' Kesu tourist attraction

\begin{tabular}{clc}
\hline No. & \multicolumn{1}{c}{ Budget Types } & $\begin{array}{c}\text { Percentage } \\
\text { of Total } \\
\text { Revenue (\%) }\end{array}$ \\
\hline 1 & $\begin{array}{l}\text { Deposited for the Regional } \\
\text { Government Budget }\end{array}$ & 40 \\
2 & Wage bill & 7 \\
3 & Preservation reserves & 7 \\
4 & Cleaning cost & 5 \\
5 & Electricity and clean water & 6 \\
6 & Maintenance of buildings & 10 \\
& and areas & 5 \\
7 & Office stationery & 12 \\
8 & Manager incentives & 2 \\
9 & Taxes (property tax and & 3 \\
& income tax) & 3 \\
\hline 10 & Office inventory & Other operations \\
\hline & Total & 100 \\
\hline
\end{tabular}

Source: Ke'te' Kesu Foundation (2018)
In addition to measuring the efficiency value of a tourist attraction, the DEA method can also provide a reference for other tourist attractions or DMUs with inefficient management to achieve efficient conditions. The results of DEA analysis show that 6 DMUs can become references to other DMUs, i.e., DMU 1 (Ke'te' Kesu), which were referred to by 9 DMUs; DMU 7 (Singki' Cross), which were referred to by 2 DMUs; DMU 11 (Palawa'), which were referred to by 12 DMUs; DMU 13 (Ne' Gandeng Museum), which were referred to by 7 DMUs; DMU 19 (Sinar Lempe), which were referred to by 2 DMUs; and, DMU 21 (Lolai To'tombi), which were referred to by 3 DMUs (Figure 3). From these 6 tourist attractions, 5 tourist attractions were managed by foundations, and the only one managed by a family is the Singki' Cross tourist attraction. The Singki' Cross, although a family managed it with the labour of 2 people and 1 toilet facility, can optimise the number of visitors and income. However, it should be considered that the efficiency value calculated in the DEA is a relative measure, and there are other controlled and uncontrolled factors that can also affect efficiencies, such as capital, natural and cultural resources, security, and others (Soysal-Kurt, 2017). To achieve optimal efficiency of $100 \%$, the tourist attractions with inefficient management can imitate the level of input use applied by the referred tourist attraction for improvement. By imitating this input level, inefficient tourist attractions will be $100 \%$ efficient by achieving maximum output targets similar to the tourist attractions that are referenced. This is the management implication that an inefficient tourist attraction can achieve a perfect efficiency level of $100 \%$.

The Londa tourist attraction was an efficient tourist attraction with a value of $\theta=1$ or $100 \%$, but it did not become a reference for other tourist attractions. DMU 14 (Londa) had original values for output 1 of 601.000 , output 2 of 970.000 , input 1 of 23.000, input 2 of 4.000, and input 3 of 388.000 , respectively. Peers that became a reference for DMU 14 were DMU 11 and DMU 1 , each with lambda weight of $\lambda_{11}=0.091$ and $\lambda_{1}=0.782$. The DEA analysis results show that 


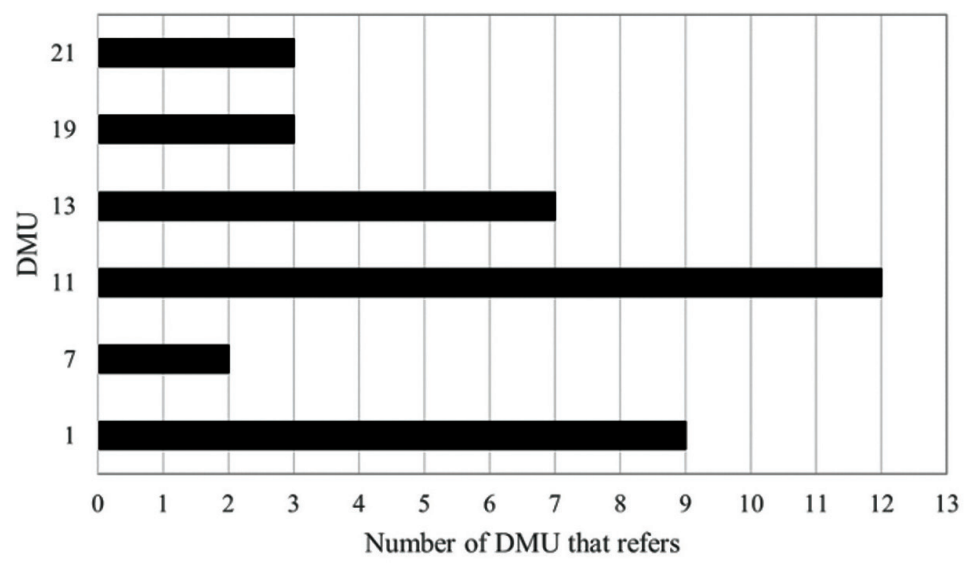

Figure 3: Reference set frequency

DMU 14 can still increase output 1 to 614.930 with a radial movement of 0.056 and a slack movement of 13.874 , while output 2 was 970.091 with a radial movement of 0.091 . The input used was input 1 of 16.601 with a slack movement of -6.399 , while input 2 and input 3 were fixed. Therefore, with the labor of 17 people, 4 toilet facilities, and deposits to the local government of IDR 388 million, the Londa tourist attraction can increase the number of visitors to 61,493 people and generate revenue of IDR 970,091 million. Londa had the second highest tourist visits with 60,149 visitors in 2018. The number of visitors includes 10,213 foreign tourists, 48,598 domestic tourists, 338 local governments, and 1,000 students. The revenue of the Londa tourist attraction in 2018 after deducting the deposit for the North Toraja Regency Regional Budget was IDR 970.48 million.

Londa is a burial area in a natural cave that is still used now. In this cave, which is hundreds of years old, wooden coffins with skulls and bones of people buried in this cave can be found. There is a statue of a person buried (tau-tau) in the cave at the cave's front. The Londa tourist attraction was founded by 15 tongkonan groups that formed the Sangpetayanan Foundation to manage Londa. The entire tongkonan will take turns every month to serve the ticket counter of the tourism object. Also, aside from serving at the ticket counter, some members who can speak English also guide tourists who visit. A total of
$60 \%$ of the funds received by the foundation were intended for the employees' wages and the tourist management office's, especially electricity. The funds raised were also used to develop and maintain tourism objects, improve family tongkonan houses, scholarships for highachieving families, and financial assistance for the Londa congregation church.

A tourist attraction that has not achieved a perfect $100 \%$ efficiency level should improve its level of input and output use that has been achieved. This means that the available inputs should be utilised optimally (to a minimum) to produce output from the set target (as much as possible). A tourist attraction that is inefficient in its management can imitate the efficient use of input and output from a tourist attraction to increase its efficiency to achieve a perfect efficiency level of $100 \%$. Managers of tourist attractions can increase productivity by considering potential improvements in several aspects, including labour, tourism support facilities, and local governments' deposits to increase visitors and income. The management plan, especially human resources management and tourism support facilities, is directed at increasing productivity. The labourmanagement plan includes the division of tasks and activity schedules, preparing management cost budget plans, and organising training activities or courses for managers. The tourism support facilities management plan includes 
planning guidelines for the standard appearance of facilities, optimising toilet facilities, and providing other tourist facilities for visitors' convenience.

The labor-management plan is carried out by creating a workforce activity program to work optimally. To achieve efficiency in managing the tourist attractions, it is necessary to have a clear division of tasks and a transparent activities schedule. Managers can make details of the types of management activities that must be carried out and the schedule, including daily, weekly, monthly, and annual activities. Besides, managers should also plan a management cost budget that includes budgets for labour, maintenance of tourist attractions, and equipment procurement. This management plan can be prepared by both foundations and non-governmental organisations to facilitate management activities. Local governments can also work with foundations and nongovernmental organisations to organise training activities or courses to improve laborers' quality of knowledge and skills. Labour skills are one of the determining factors that can affect tourism performance (Assaf \& Josiassen, 2012), so it is important to manage tourist attractions. Tourist attraction managers must have the knowledge, hard skills, and soft skills to provide satisfaction and memorable experiences to tourists (Adeyinka-Ojo, 2018). For facility management, managers can optimise existing toilet facilities by keeping toilets clean. Managers can also provide other tourist facilities, such as places to eat and worship as amenities for visitors. Still, these facilities' construction must be done correctly with minimal impact on the environment (Sadikin et al., 2017). Managers need to make the appearance of a standard of tourism support facilities, such as toilet performance standards, which can be used as guidelines for managers, clean from rubbish, no standing water and not slippery, with clean water sources, and toilets that function properly.

\section{Conclusion}

The analysis of tourist attractions management's efficiency shows 7 tourist attractions whose management is efficient and 14 tourist attractions whose management is inefficient. Attractions that had efficient management were Ke'te' Kesu, Singki' Cross, Palawa', Ne' Gandeng Museum, Londa, Sinar Lempe, and Lolai To'tombi. Six tourist attractions become a reference or benchmark for the other tourist attractions from the seven efficient tourist attractions. Inefficient tourist attractions can optimise labour, facilities owned, and funds obtained to be efficient. Also, inefficient tourist objects can refer to tourist attractions that are efficient in managing their resources to optimise visitors and income. It is recommended for the inefficient management of tourist attractions to improve the management efficiency by optimising labour and various tourism support facilities. Increasing the labour capacity can be done through various training or courses to improve the labour knowledge and skills to provide tourists with optimal services.

\section{Acknowledgements}

Funding for this research was obtained through the Scholarship of Excellence for Indonesian Lectures (BUDI) (Contract Number: PRJ6220/LPDP.3/2016, November 2016). Therefore, the authors express gratitude to the Ministry of Research, Technology and Higher Education (Kemenristekdikti) and the Indonesia Endowment Fund for Education (LPDP) of the Republic of Indonesia for financial support.

\section{References}

Adeyinka-Ojo, S. F. (2018). A strategic framework for analysing employability skills deficits in rural hospitality and tourism destinations. Tourism Management Perspectives, 27(3), 47-54.

Agasisti, T., Munda, G., \& Hippe, R. (2019). Measuring the efficiency of European education systems by combining data envelopment analysis and multiple- 
criteria evaluation. Journal of Productivity Analysis, 51(2-3), 105-124.

Alzua-Sorzabal, A., Zurutuza, M., Rebon, F., \& Gerrikagoitia, J. K. (2015). Obtaining the efficiency of tourism destination website based on data envelopment analysis. Procedia - Social and Behavioral Sciences, 175, 58-65.

Assaf, A. G. (2012). Benchmarking the Asia Pacific tourism industry: A Bayesian combination of DEA and stochastic frontier. Tourism Management, 33, 1122-1127.

Assaf, A. G., \& Josiassen, A. (2012). Identifying and ranking the determinants of tourism perfomance: A global investigation. Journal of Travel Research, 51(4), 388-399.

Assaf, A. G., \& Josiassen, A. (2015). Frontier analysis: A state-of-the-art review and meta-analysis. Journal of Travel Research, 55(5), 612-627.

Barros, C. P. (2005). Measuring efficiency in the hotel sector. Annals of Tourism Research, 32(2), 456-477.

[BPS] Badan Pusat Statistik Kabupaten Toraja Utara. (2019). Kabupaten Toraja Utara dalam Angka. Rantepao (ID): Badan Pusat Statistik Kabupaten Toraja Utara.

Chaabouni, S. (2019). China's regional tourism efficiency: A two-stage double bootstrap data envelopment analysis. Journal of Destination Marketing and Management, 11, 183-191.

Chen, T., Chen, C. B., \& Peng, S. Y. (2008). Firm operation performance analysis using data envelopment analysis and balanced scorecard: A case study of a credit cooperative bank. International Journal of Productivity and Performance Management, 57(7), 523-539.

Cooper, W. W., Seiford, L. M., \& Tone, K. (2000). Data envelopment analysis: A comprehensive text with models, applications, references and DEA-Solver software. New York (NY): Kluwer Academic Publishers.
Despotis, D. K., \& Smirlis, Y. G. (2002). Data envelopment analysis with imprecise data. European Journal of Operational Research, 140, 24-36.

Erislan. (2016). Tourist attraction and the uniqueness of resources on tourist destination in West Java, Indonesia. Review of Integrative Business \& Economics Research, 5(1), 251-266.

Fauzi, A. (2019). Teknik Analisis Keberlanjutan. Jakarta (ID): PT Gramedia Pustaka Utama.

Fuentes, R. (2011). Efficiency of travel agencies: A case study of Alicante, Spain. Tourism Management, 32, 75-87.

Itamar, H., Alam, A. S., \& Rahmatullah. (2014). Strategi pengembangan pariwisata di Kabupaten Tana Toraja. Government Journal Ilmu Pemerintahan, 7(2), 91-108.

Jafari, J., \& Xiao, H. (2016). Encyclopedia of Tourism. Switzerland (CH): Springer Reference.

Jiang, H., Han, L., Ding, Y., \& He, Y. (2018). Operating efficiency evaluation of China listed automotive firms: 2012-2016. Sustainability (Switzerland), 10(184), 1-22.

Junaid, I. (2015). Sustainable tourism in Toraja: Perspective of indigenous people. ASEAN Journal on Hospitality and Tourism, 14, 45-55.

[Kemenpar] Kementerian Pariwisata. (2019). Laporan Akuntabilitas Kinerja Kementerian Pariwisata Tahun 2018. Jakarta Pusat (ID): Kementerian Pariwisata Republik Indonesia.

Khan, A., Bibi, S., Lorenzo, A., Lyu, J., \& Babar, Z. U. (2020). Tourism and development in developing economies: A policy implication perspective. Sustainability, 12(1618), 1-19.

Klimberg, R. K., Lawrence, K. D., Yermish, I., Lai, T., \& Mrazik, D. (2009). Using regression and data envelopment analysis (DEA) to forecast bank performance over time. Applications of Management Science, 13, 133-142. 
Kohl, S., Schoenfelder, J., Fugener, A., \& Brunner, J. O. (2019). The use of data envelopment analysis (DEA) in healthcare with a focus on hospitals. Health Care Management Science, 22(2), 245-286.

Liu, Y. L., \& Ko, P. F. (2011). A visitor-focused study of tourism attraction in Taiwan: Empirical evidence from outbound Chinese tourists. Journal of Hospitality Management and Tourism, 2(2), 22-33.

Malamassam, D. (2018). Pembangunan kepariwisataan berbasis riset dan teknologi - pembangunan kepariwisataan terintergrasi (wisata alam, wisata agro, dan wisata budaya) di Tana Toraja. In E. Lolang (Ed.), Prosiding Semkaristek Seminar Nasional Kepariwisataan Berbasis Riset dan Teknologi (pp. 1-11). 2018 Sep 6-7; Tana Toraja, Indonesia. Makale (ID): Penerbit UKI Toraja Press.

Mandic, A., Mrnjavac, Z., \& Kordic, L. (2018). Tourism infrastructure, recreational facilities and tourism development. Tourism and Hospitality Management, 24(1), 41-62.

Mhlanga, O. (2018). Factors impacting restaurant efficiency: A data envelopment analysis. Tourism Review, 73(1), 82-93.

Mostafa, M. M. (2007). Modelling the efficiency of GCC banks: A data envelopment analysis approach. International Journal of Productivity and Perfomance Management, 56(7), 627-643.

Oliveira, R., Pedro, M. I., \& Marques, R. C. (2013). Efficiency and its determinants in Portuguese hotels in the Algarve. Tourism Management, 36, 641-649.

Othman, F. M., Mohd-zamil, N. A., Rasid, S. Z. A., Vakilbashi, A., \& Mokhber, M. (2016). Data envelopment analysis : A tool of measuring efficiency in banking sector. International Journal of Economics and Financial, 6(3), 911-916.

Oukil, A., Channouf, N., \& Al-Zaidi, A. (2016). Performance evaluation of the hotel industry in an emerging tourism destination: The case of Oman. Journal of Hospitality and Tourism Management, 29, 60-68.

Palalangan, C. A., Paranoan, N., \& Pasanda, E. (2019). Tata kelola keuangan pada objek wisata Ke'te' Kesu di Kabupaten Toraja Utara. Jurnal Buana Akuntansi, 4(2), 5972.

Sadikin, P. N., Arifin, H. S., Pramudya, B., \& Mulatsih, S. (2017). Carrying capacity to preserve biodiversity on ecotourism in Mount Rinjani National Park, Indonesia. Biodiversitas, 18(3), 978-989.

Sherman, H. D., \& Zhu, J. (2006). Service productivity management improving service performance using Data Envelopment Analysis (DEA). New York (NY): Springer.

Sofronov, B. (2018). The development of the travel and tourism industry in the world. Annals of Spiru Haret University, Economic Series, 18(4), 123-137.

Soysal-Kurt, H. (2017). Measuring tourism efficiency of European countries by using Data Envelopment Analysis. European Scientific Journal, 13(10), 31-49.

Szpilko, D. (2017). Tourism supply chainoverview of selected literature. Procedia Engineering, 182, 687-693.

Tsai, H. (2009). Star-rated hotel productivity in China: A provincial analysis using the DEA cross-efficiency evaluation approach. Journal of China Tourism Research, 5(3), 243-258.

Tugcu, C. T. (2014). Tourism and economic growth nexus revisited: A panel causality analysis for the case of the Mediterranean Region. Tourism Management, 42, 207212.

[UNWTO] United Nation World Tourism Organization. (2019). International Tourism Highlights 2019 Edition. Madrid: UNWTO.

Yi, T., \& Liang, M. (2014). Evolutional model of tourism efficiency based on the DEA method: A case study of cities in Guangdong 
Province, China. Asia Pacific Journal of Zhou, H., Yang, Y., Chen, Y., \& Zhu, J. (2018). Tourism Research, 20(7), 1-18.

Data envelopment analysis application in

Zhang, J., \& Guo, Y. (2004). The relationship between the number of factors and DEA efficiency. Systematic Engineering-Theory, sustainability: The origins, development and future directions. European Journal of Methodology and Applications, 13(6), 520Operational Research, 264(1), 1-16. 523. 